\title{
Editorial
}

\section{Making Way in the Cross Currents}

\author{
Bruce Kaye
}

Ten years ago I found myself sailing in a part of the Coral Sea off the northeast coast of Australia called the Whitsunday Passage. It is a stretch of water, about fifteen miles across and thirty miles long, created by a group of offshore islands. There are some strong currents and big tides. After a week of sailing we were coming back into the harbour and on full sail we seemed not to be making very much progress. I had failed to take account of the fact that we were returning against the tide, which was running very fast. So with a sailor's embarrassment we had to add the power of the motor to that of the sails and by this means we made it to the harbour. Making way was not easy in the contrasting currents of tide and wind. It seems to me that it is the same with Christian faith. We are heirs to a tradition of faith that is committed to belief in the redemptive revelation of God, in the person of Jesus Christ, in the continuing leading of the Holy Spirit and in the vocation to live out the character of our faith in the circumstances in which God has placed us. The tradition of faith in Christianity does not allow definitive knockdown answers to every particular question in our lives. Scripture makes it clear that we walk by faith not by sight.

What is true of Christianity, generally is also true of its subtraditions, of which Anglicanism is one example. Within a subtradition there will be some more particular commitments than are to be found in the generality of Christianity. For one thing, Anglicans generally have had a liturgical tradition and have retained a threefold order of ministry in the church together with a shared memory of faith. There will also be currents within Anglicanism that appear from time to time which not all Anglicans embrace. Sometimes those currents will be easily visible in the sails, on other occasions they will not be seen but felt or sensed, just as is the influence of the tide.

I do not want to stretch the analogy too far, but it seems to me that a tradition like Anglicanism is quite properly struggling to make its way in a context of cross-currents and changes. It becomes, therefore, 
important to have some sense of the identity of the tradition as it moves from side to side, and sometimes forward, so that appropriate responses can be made to the currents felt by the participants. A sense of continuity does not mean sameness from one generation to the next. It means that there is something recognizable in the underlying operation of the tradition as the faith is passed on from generation to generation. Anglicans have changed their minds on a lot of things over the years-polygamy, divorce, slavery and the particulars of church governance, and many Anglicans have adopted views and practices that not all have embraced. These latter have included such central matters as the meaning of the sacraments and the character of the authority of scripture and its interpretation, to mention just two.

This situation is not peculiar to Anglicans. Indeed it is common in all traditions of Christianity and is embedded in the biblical narrative. When the elders of Israel came to Samuel and asked for a king like the nations around them, Samuel was affronted. Perhaps, he saw it as a rejection of his role as a prophet. The biblical text, however, sees it as a rejection of the theocratic rule of God in Israel. Nonetheless, Samuel is told by God to allow their request and to participate in the appointment and anointment of such a king. Thus, by this narrative, the whole idea of kingship is rendered ambiguous in the tradition of Israel's faith.

In the New Testament, Jesus' claim to fulfil the law and the prophets does not mean that he is abolishing the law, nor does it mean that he is repristinating it. Rather, it shows that Jesus' mission effects a new beginning that has continuities with the past and also significant discontinuities. Within the corpus of documents in the New Testament there is noticeable diversity not only of expression, but also of what is being expressed on a given theme. Yet, at the same time that diversity sits within a broader framework of some clear coherence. Unity and diversity in the New Testament has been the subject of much scholarly attention, not just in the modern period since Walter Bauer's famous book. ${ }^{1}$ Writers in early Christianity show an awareness of the issue and 2 Peter 3.15f. reports the difficulty some felt in understanding what Paul was on about in his letters. That the gospels present the stories about Jesus in different orders was very early seen and Eusebius of Caesarea developed a numerical coding system to identify

1. W. Bauer, Rechtglaubigkeit Und Ketzerei Im Altesten Christentum (Eng.Tr.1972, Orthodoxy and Heresy in Earliest Christianity, London) (Tubingen: Mohr/Siebeck, 1934). 
these differences. ${ }^{2}$ Eusebius was well aware that the gospel writers put things in different places, but asserted that they did so for good reasons of speaking the truth. 'Keeping, however, both the body and sequence of the other gospels completely intact, in an order that you may be able to know where each evangelist wrote passages wherein they were led by love of truth to speak about the same things, I drew up a total of ten tables according to another system, acquiring the raw data from the work of the man mentioned above (Ammonius) ${ }^{3}{ }^{3}$

That such diversity is seen as an expression of the truth rather than a fatal contradiction on the grounds of inconsistency shows that the issue is about recognizable identity rather than uniformity as the basis of shared understanding of the faith and thus of fellowship. That pattern quickly developed at the local level with issues of discipline over moral conduct that we can see in the letters of Paul. At a wider level it was less immediate, yet still there was a relationship of fellowship and mutual belonging that was different from the intensity of the local relationships. There was clearly a sense of all Christians belonging to each other and as Christianity extended, it became both more diffuse and more general.

As Christianity spread within the Roman world, the church in Rome naturally gained a pre-eminent recognition, enhanced by the association of Peter with that church. In the later centuries, Rome claimed a more significant preeminence that reached a pinnacle with the reforms of Pope Gregory VII in the eleventh century. By this time many subtraditions had developed and no one church could sensibly claim such a universal priority. The idea of one universal church held within a single juridical structure has never been sustainable. Such thought of a single or one, Holy Catholic Church rightly belongs in the realms of eschatology. The emergence of different traditions and ecclesial structures has all the ambiguities of the inauguration of kingship into the theocracy of Israel. It emerges as under the providence of God, yet it has about it the marks of sin and rebellion.

Such a situation means that in ecclesial life, as in the personal life of the Christian person, we walk by faith, according to such recognisable light as we have made available to us. In that context, the church is always

2. These are the so-called Eusebian canons originally attributed to the second century Christian philosopher, Ammonius of Alexandria, but now generally regarded as the work essentially of Eusebius of Caesarea (Bauer, Rechtglaubigkeit Und Ketzerei Im Altesten Christentum, pp. 263-339).

3. See the text of his letter to Carpianus at http://www.tertullian.org/ fathers/eusebius_letter_to_carpianus.htm 
enquiring after the call of God. We are seeking to find the way that will enable us to be faithful to our calling and to be witnesses to the Gospel of Christ crucified and risen. Such exploration inevitably leads to different visions and to different judgments. The struggle and joy of Christian living is to listen to the gifts others have in the church as we seek to learn and to be built up in the faith. That is easier said than done and it is no wonder that the enduring divine virtue identified by Paul is love and not agreement, though agreement is a blessed gift as well.

It is in this context that the theologian emerges as the successor of Samuel and the prophets. As bearers of the knowledge of the tradition and servants of the community they are, to use a phrase of Michael Ramsey, 'exposed to the vision of heaven and to the tragedies of mankind'. ${ }^{4}$ Theologians, thus, serve in an exploration and an argument, and demonstrate the divine character of their vocation by the manner in which they conduct that exploration and argument. When we began in the Journal of Anglican Studies we set out to serve that vocation. In the Editorial of the first issue we set it out this way.

All of this points to the fact that in the current global circumstances, as Anglicans we need to engage in serious and committed conversation about the distinctives of the Anglican tradition and its experience of such plurality in a shared faith tradition. The Journal of Anglican Studies sets out to provide for and to encourage that conversation among Anglican scholars around the world. ${ }^{5}$

Theologians pursue this vocation in very many different ways. In the present context of disputes about Anglican identity themes that involve re-reading and re-discovering the tradition performing a vital contribution to the living memory of Anglicans and their ecclesial communities. Similarly, studies that explore the nature of the interface between that tradition and the contemporary context, in which we are called to be faithful, are vital to our making way amidst contemporary currents.

The historical moment in which we live is marked by imperial power present in all sorts of forms. The most obvious is the current military super power status of the United States, but also powerfully present is the recent history of colonialism, so closely allied to the formation of Anglican communities around the globe. A recent

4. A.M. Ramsey, 'Looking to the Future', in A. Vogel (ed.), Theology in Anglicanism (Wilton: Morehouse Barlow, 1984), pp. 159-62.

5. B. Kaye, 'Editorial', Journal of Anglican Studies (2003), vol. 1.1, p. 7. 
publication on Empire and the Christian Tradition, ${ }^{6}$ thus naturally attracts our attention. The book is a collection of thirty-two articles by different authors in which a particular theologian is examined in terms of their treatment of the theme of empire. Those treated in this way include the apostle Paul, Augustine, Anselm of Canterbury, Thomas Aquinas, Julian of Norwich, William Temple and John Mbiti. The contributors to the book mostly come from the United States and show a critical awareness of the ambiguities of the current American position as a world power. There are three introductory essays. Don Compier provides a reader's guide to the project, Kwok Pui-Lan canvasses the relation between theology and social theory, which also deals with the postcolonial critique, and there is an important section on theology, empire and social imagery.

However, the essay I wish particularly to draw attention to is that by Joerg Rieger on 'Christian Theology and Empires'. The plural 'Empires' proves to be significant in his argument, as we shall notice later. First, Rieger points out that empire has been around from the beginning and throughout most of Christian history. Simple reaction of opposition or acceptance of the benefits or threats of empire may have been relevant from time to time, but are not adequate to our present situation. The relationship between empire and Christianity is in fact more complex. By empire he means the 'massive concentrations of power that permeate all aspects of life and that cannot be controlled by one actor alone'. ${ }^{7}$ Broadening the definition beyond the merely political enables him to uncover the wide variety of forces that shape life in the modern world aside from the strictly political. These could include what he calls the softer forms of colonialism, the power of 'civilization' that played such a significant role in the colonial and missionary drive of the nineteenth century.

How does this relate to the practice of theology both now and in the past. There are clear ambiguities in all this. He says, interestingly, that both Nicea and Chalcedon rejected hierarchical understandings of the relationship between the Father and the Son, and also between the human and divine in Jesus 'despite general support for political and metaphysical hierarchies'. ${ }^{8}$ The trouble is that the real power is often not easily visible and in the contemporary world other forms of power affect relations between nations and peoples. Power differentials, he says, are still at the heart of the problem.

6. Don H. Compier, Pui-lan Kwok and J. Rieger, Empire and the Christian Tradition: New Readings of Classical Theologians (Minneapolis: Fortress Press, 2007).

7. Compier, Empire and the Christian Tradition, p. 3.

8. Compier, Empire and the Christian Tradition, p. 10. 
This is not a new problem, as the essays in this book make clear. But it is an enduring challenge not only for how we are to understand the relation between nations and people, but also how we are to understand relations between churches and Christians in the ecclesial community. Rieger concludes this excellent essay;

If the power of empire is as widely dispersed as I have argued and if
these powers are expanding not only geographically but also on many
other levels - including those that shape our intellectual endeavors and
our deepest personal identities - we need to investigate these powers
if we want to understand ourselves and our own theological pre-
suppositions and productions.

There is no doubt that these are rich themes and they point to a history of the Christian endeavour of our predecessors which can serve us in our own generation to make sense of our Christian vocation in relation to the powers of the age. The essays are not simply summaries of the theological views of each subject. Rather, they are re-readings of the work of these theologians in the light of the theme of the empire. They represent just the sort of reading of the tradition in relation to a contemporary question that we, and theologians in particular, need to do as we confront the challenge to live faithfully as Christians in our own time and place.

It is thus remarkable that in the current debates about Anglican identity and the nature of the relationship between Anglican churches around the world that this theme of power, or empire, has been simply lurking in the shadows on the sidelines. This collection of essays, with so much drawn from the past might help us to do a better analysis of the Anglican condition. We certainly welcome in the Journal of Anglican Studies contributions from theologians around the world on this aspect of the Anglican heritage.

Digging into the past is not the only element in our discernment of God's calling. Exploring what the contemporary means is also part of the living out of the Gospel to which we are called. This aspect is also a critical part of the theologians' service to the church and thus attracts the interest of the Journal of Anglican Studies. A great deal of work has been done on this theme by African theologians and their work has seen expression in liturgy, music and literature. The balance between adaptation and critique is central in this body of work and can be seen in the work of any number of theologians. John S. Pobee is one among them and he set out his thoughts in a brief compass in a remarkable

9. Compier, Empire and the Christian Tradition, p. 13. 
little book published in 2000 entitled Invitation to be African Anglican. ${ }^{10}$ Pobee has published many articles and books during his time as a professor of Theology at the University of Ghana and as a director for fifteen years of the programme on theological education and ministerial formation for the World Council of Churches in Geneva. He has served on the International Doctrinal and Theological Commission of the Anglican Communion.

When he returned to Ghana he turned to the theological education and formation and ministry of all God's people in his own Anglican church in Ghana. This little book is an expression of this endeavor. The first six chapters deal with standard themes of the church, the origins of Anglicanism, scripture, traditions, sacraments and episcopate. Two chapters on the background of the church in Africa follow and a final chapter on directions to explore. Pobee focuses on two polarities, Anglican identity and the context of life of the people. A fundamental issue he says is 'how to make Anglicanism's commitment to the vernacular paradigm real in a multi-ethnic context, and more so, to the masses of nonliterates'. ${ }^{11}$

This 'vernacular paradigm' runs through everything in the book. It is not simply language translation but is intercultural in character, and it is multi-faceted in that it embraces music, liturgy and action, not just the words in texts. It affects the way things are done in the church and the way the church functions as an institution. Thus, 'the interpretation of Anglicanism in Africa is an exercise in inter-cultural and interreligious encounter and engagement'. ${ }^{12}$

These two books neatly express the past and present dimensions of the theological task for Anglicans in making way in the cross-currents of our present lives. They are themes that have recurred in the contributions to the Journal of Anglican Studies and will continue to appear as we support and encourage the theological task of finding our way in the cross-currents of today's world and the church.

In this issue of the Journal of Anglican Studies we publish a number of articles that touch on these matters. Noel Cox gives us a detailed account of the Church-State relationships in New Zealand; Brian Douglas and Terry Lovat offer a way of approaching the church conflict over liturgy in Australia and Andrew Village and Leslie Francis show how evangelicals and Anglo Catholics in the Church of

10. John S. Pobee, Invitation to be African Anglican (Accra: Asempa Publishers, 2000).

11. Pobee, Invitation to be African Anglican, p. xi.

12. Pobee, Invitation to be African Anglican, p. 118. 
England are changing in their attitudes to the church and social issues. Dwight Zscheile draws attention to contextualization moves in The Episcopal Church in the United States and argues for a different approach to mission in that church. Jason Bruner tackles directly the framework for understanding some of the alliances in the current divisions among Anglicans worldwide and in the process challenges Philip Jenkins next Christendom model. They are examples of the enduring challenge for theologians as they seek to assist Christians in their vocation in today's world. They are themes that have recurred in the Journal of Anglican Studies and with which we encourage theologians to engage.

With this issue of the Journal of Anglican Studies, Rowan Strong leaves us as an associate editor, and in his place we are joined by Dr James Rigney. We thank Rowan very much for his contribution to the Journal of Anglican Studies and look forward to working with James. 